\title{
TINJAUAN SOSIO-POLITIK TERHADAP LARANGAN POLIGAMI (Pembaharuan Hukum Keluarga Tunisia)
}

\author{
Ahmad Bahauddin AM \\ Dosen UIN Raden Fatah Palembang \\ Dosen STIT Makrifatul IImi Bengkulu Selatan \\ Email : bahauddinahmad.am@gmail.com
}

\begin{abstract}
The practice of polygamy which is carried out by some Tunisian society generally torments the wife. This is the basis for the prohibition of polygamy in Tunisia. The purpose of this research is to find out about the prohibition of polygamy in Tunisia which is contained in the Tunisian Family Law. This study uses literature research that focuses on the object of study on existing books and literature. While the method used in this research is descriptive-analysis method, which provides an overview and analyzes the Tunisian family law regarding the prohibition of polygamy. The results of this study indicate that the Tunisian State in implementing the law on the prohibition of polygamy cannot be separated from social politics. The factor is the number of husbands who torment their wives and children. This is one of the reasons that makes the law on the prohibition of polygamy come into effect. Because of the injustice committed by husbands to their wives. But in reality the regulations on the prohibition of polygamy are still not running optimally. This is because there is no common will between the government and the people.
\end{abstract}

Keywords: Polygamy, Tunisia, Family Law

\begin{abstract}
Abstrak
Praktek poligami yang dilakukan oleh sebagian masyarakat Tunisia pada umumnya menyengsarakan pihak isteri. Inilah yang menjadi dasar pelarangan Poligami di Tunisia. Tujuan penelitian ini adalah mencari tau terhadap pelarangan poligami di Negara Tunisia yang termuat dalam Hukum Keluarga Tunisia. Penelitian ini menggunakan penelitian kepustakaan yang memfokuskan pada objek kajian pada buku-buku dan literature yang ada. Sedangkan metode yang digunakan dalam penelitian ini adalah metode deskriptif-analisis, yaitu memberikan gambaran dan menganalisis Hukum Keluarga Tunisia terkait tentang pelarangan poligami. Hasil dari penelitian ini menunjukkan bahwa Negara Tunisia dalam penerapan undang-undang tentang larangan poligami tidak lepas dari social politik. Faktornya ialah dengan banyaknya para suami yang menyengsarakan pihak isteri dan anak. Inilah salah satu penyebab yang menjadikan berlakunya perundang-undangan tentang larangan poligami.
\end{abstract}


Karena ketidakadilan yang dilakukan suami terhadap para isterinya. Tetapi pada kenyataannya peraturan larangan poligami tersebut berjalan masih belum maksimal. Ini disebabkan karena tidak adanya kesamaan kehendak antara pemerintah dan masyarakat.

Kata Kunci : Poligami, Tunisia, Hukum Keluarga

\section{A. Pendahuluan}

Tunisia memperoleh kemerdekaan pada tahun 1956, merupakan suatu negara berbentuk republika yang dipimpin oleh seorang presiden dan Islam merupakan agama resmi di Negara Tunisia. Mayoritas masyarakatnya sekitar $98 \%$ adalah muslim Sunni, negara yang terletak di Afrika Utara, sebelah barat berbatasan dengan Mediterania dan selatan Libya. Tunisia termasuk kepulauan Karkunna untuk daerah timur, sementara di bagian tenggara termasuk kepulauan Djerba. Negara yang memiliki luas wilayah $163.610 \mathrm{~km}^{2}$ dan membawahi 23 Provinsi dengan presiden pertama Habib Bourguiba. Sebelumnya Tunisia merupakan wilayah otonom dari pemerintahan Turki Usmani dan pada tahun 1883 menjadi negara persemakmuran Perancis berdasarkan perjanjian La Marsa. ${ }^{1}$

Pada tahun 1956 Presiden Habib Bourgubia mengeluarkan aturanaturan kontroversial yang dinamakan personal status code untuk menggantikan hukum al-Quran dalam bidang perkawinan, perceraian dan hadanah. Seiring dengan itu pemerintah legeslatif memodifikasi banyak hukum-hukum sebelumnya dan menerapkan hukum baru antara perdata dan pidana atau sipil dan kriminal. Aturan-aturan baru ini tidak hanya menentang beberapa praktek muslim tradisional bahkan menyatakan konfrontasi dengannya, sesuatu yang tidak pernah dilakukan bangsa Perancis. Berdasarkan konstitusi Tunisia, Islam adalah agama resmi negara. Sedangkan mazhab Maliki mempunyai pengaruh yang sangat dominan di negara tersebut. Latar belakang negara Tunisia memberi

${ }^{1}$ John P. Entelis, "Tunisia" dalam John L. Esposito dkk. (ed) The Oxport Encyclopedia Of The Modern Word, (New York: Oxford University Press, 1995), IV HIm. 236 
gambaran kepada kita setidaknya di Tunisia pernah pula berlaku hukum Islam (fiqh) berdasarkan mazhab Hanafi, sebagai pengaruh yang dibawa oleh pemerintah dinasti Usmani. ${ }^{2}$

\section{B. Sejarah Hukum Keluarga Tunisia}

Sejarah lahirnya kodifikasi dan reformasi hukum keluarga Tunisia tersebut berawal dari adanya pemikiran dari sejumlah ahli hukum terkemuka Tunisia yang berfikir bahwa dengan melakukan fusi terhadap mazhab Hanafi dan mazhab Maliki, sebuah ketentuan hukum baru mengenai hukum keluarga dapat dikembangkan sesuai dengan perkembangan situasi dan kondisi sosial kemasyarakatan Tunisia. Sejumlah ahli hukum Tunisia kemudian mengajukan catatan perbandingan antara dua system hukum Hanafi dan Maliki yang kemudian dipublikasikan dengan judul Laihat Majjalat al-Ahkam alsyar'iyyah (Draft Undang-undang Hukum Islam). Pada akhirnya pemerintah Tunisia membentuk sebuah komite di bawah pengawasan Syeikh Islam Muhammad Ja'it untuk merancang undang-undang secara resmi. ${ }^{3}$

Komite tersebut kemudian merancang dan mengajukan rancangan Undang-undang Hukum Keluarga kepada pemerintah. Rancangan tersebut bersumber dari Laihat Majjalat al-Ahkam alsyar'iyyah, selain itu juga bersumber dari Hukum Keluarga Mesir, Jordania, Syria dan Turki Utsmani. Setelah disetujui pemerintah rancangan tersebut akhirnya diundangkan pada tanggal 1 Januari 1957 dengan nama Majjalah al Ahwal al Syakhsiyyah (Code of Personal Status) 1956 yang berisikan 170 pasal. Undang-undang ini mengalami beberapa kali perubahan dan penambahan dengan ketentuan-ketentuan baru. ${ }^{4}$

${ }^{2}$ M. Atho' Muzdhar dan Khairuddin Nasution, Hukum Keluarga Di Dunia Islam Modern, (Jakarta: Ciputat Press, 2003) HIm. 84 Law...,h.152

${ }^{3}$ Atho Muzdhor dan Khaoiruddin Nasution, Hukum Keluarga ...,h. 86. Tahir Mahmod, Personal

${ }_{4}^{4}$ Perubahan tersebut adalah UU No. 70 tahun 1958 dengan perubahan pada pasal 18 tentang poligami, UU No. 77 tahun 1969, pasal yang dirubah adalah pasal 143 A tentang radd, buku IX tentang kewarisan, buku XI tentang wasiat, UU No. 41 tahun 1961, pasal yang dirubah adalah pasal 32 tentang perceraian, UU no. 17 tahun 1964 yang dirubah adalah buku XII tentang hibah, dan terakhir UU No. 49 tahun 
Setelah diamandemen tahun 1966 The Tunisian Code of Personal Status berisi 213 pasal yang meliputi : perkawinan (pasal 10-28), perceraian (29-33), idda (34-36), nafkah (37-53A), pemeliharaan anak (5467), perwalian (68-76), anak terlantar (77-80), orang hilang (81-84), kewarisan (85-152), cakap hukum (153-170), wasiat (171-199), dan hibah (200-213). ${ }^{5}$

Pada tahun 1981 ditetapkan sebuah undang-undang baru yang merupakan modifikasi dari undang-undang keluarga tahun 1956. Undangundang tahun 1981 ini berdasarkan rekomendasi dari komite yang terdiri dari ahli hukum, yaitu pengacara, hakim, dan pengajar hukum yang diketuai oleh menteri hukum. Proposal komite ini berdasarkan pada interpretasi bebas terhadap hukum syari'ah yang berhubungan dengan hak-hak keluarga.

\section{Poligami dalam Undang-undang Keluarga Tunisia}

1. Lahirnya Perundangan Poligami dalam kacamata Sosial Politik

Secara global sosial politik sangat melatarbelakangi lahirnya perundangan terhadap larangan poligami. Adanya kontak social politik antara Tunisia dan Perancis (1885-1912), tidak kurang dari 3000 warga Tunisia dikirim belajar ke Paris, sebaliknya orang-orang Paris melakukan kolonialisme di Tunisia. Dari sini maka muncul gerakan reformasi pemikir Muslim Tunisia yang dipengaruhi oleh pemikiran barat dengan melahirkan UU Keluarga Tunisia pada tahun 1956 termasuk di dalamnya disebutkan penjelasan tentang poligami. ${ }^{6}$

Pada tahun 1906 tercatat 34.000 orang perancis tinggal di Tunisia. Mereka memperkenalkan pertanian dan pendidikan modern kepada masyarakat Tunisia. Sedangkan orang-orang Tunisia yang belajar ke paris dan kembali ke Tunisia, mereka melakukan pembaharuan pendidikan melalui Zaituna dan Sadiqi College yang kemudian melahirkan

1966, adapun pasal yang dirubah adalah pasal 57, 64, dan pasal 67 tentang pemeliharaan anak. Lihat Tahir Mahmod, Personal Law.., h.152-4

5 Ibid., h.43-44

6 M. Atho Muzhar, Membaca Gelombang Ijtihad: antara Tradisi dan Liberasi, cet. I (Yogyakarta: Titian llahi Press, 1998), h. 112. 
Khalduniyyah College. Organisasi ini dalam perkembangan sejarah pembaharuan di Tunisia menjadi pusat gerakan yang disebut "Yhe Young Tunisians."

Sejak tahun 1883 sampai pertengahan abad ke-20, Tunisia masih dipengaruhi politik Perancis. Selama periode ini, budaya hukum Tunisia mengalami pembaratan yang semakin meluas. Hukum sipil, kriminal, komersial dan prosedural yang dibuat di Tunisia sampai tahun 1956 sebagian besar merefleksikan prinsip-prinsip perundangan dan hukum sipil Perancis. Pada tahun 1957 setahun setelah merdeka, Tunisia melalui konstitusinya mengumumkan bahwa Tunisia menjadi negara Republik. Kondisi ini merupakan langkah awal akan perumusan undangundang nasional yang secara umum memodifikasi beberapa hukumhukum sebelum kemerdekaan dan mengambil beberapa hukum baru, baik berupa sipil, kriminal maupun hukum keluarga. ${ }^{7}$

Pada tahun 1956 presiden Habib Bourguiba menetapkan Code of Personal Status/ Majallat al-Ahwal asy-Syakhsiyah (Undang-undang Keluarga) No. 66 Tahun 1956 sebagai hukum keluarga nasional. Isi undang-undang ini diantaranya menyatakan bahwa poligami dilarang secara mutlak dan menghukum orang yang melanggar aturan tersebut. Bahkan pada tahun 1964, palaku poligami bukan saja dapat dikenakan hukuman, tetapi juga dinyatakan bahwa perkawinannya tidak sah. ${ }^{8}$

Pada tanggal 10 Agustus 1956 Habib Bourguiba menjelaskan bahwa larangan poligami adalah satu pembaharuan yang sudah lama menjadi tuntutan. Poligami merupakan bentuk perkawinan yang tidak mungkin diizinkan pada abad ke-20 dan tidak mungkin dilakukan oleh orang yang mempunyai pikiran benar. Habib Bourguiba berpendapat bahwa hukum itu sebenarnya tidak bertentangan dengan prinsip Islam

\footnotetext{
7 Tahir Mahmood, Statutes of Personal Law in Islamic Coutries: History, Texts and analysis, Edisi revisi II (New Delhi: ALR, 1995), hlm. 42-43.

8 Dawoud El-Alami dan Hinchliffe, Islamic Marriage and Divorce Laws of the Arab World (London: The hague, Boston: Kluwer Law International, 1996), h. 173; Carolin Fluehr-Lobban, Islamic Siciety in Practice (Florida: University Press of Florida, 1994), h. 120.
} 
manapun. Kebolehan poligami menurut al-Quran tidak dimaksudkan untuk dilakukan disemua tempat dan waktu. ${ }^{9}$

Praktek poligami yang dilakukan oleh sebagian pelaku masyarakat Tunisia pada umumnya menyengsarakan pihak isteri. Inilah yang menjadi dasar pelarangan Poligami di Tunisia. Dengan demikian, praktek poligami yang ada tersebut tidak sejalan dengan syarat yang diharuskan al-Quran. Berdasarkan fakta inilah kemudian dirumuskan sebuah aturan formal yang bertujuan melarang praktek poligami di Tunisia. ${ }^{10}$

Dalam perkembangannya, Undang-undang Keluarga Tunisia mengalami beberapa kali perubahan, yakni dari UU No. 70 Tahun 1958, Hukum No. 77 Tahun 1959, UU No. 61 Tahun 1961, UU No. 1 dan 17 Tahun 1964, UU No. 49 Tahun 1966, dan UU No. 7 Tahun 1981. Walaupun beberapa kali mengalami amandemen, pasal yang mengatur tentang poligami secara substansi tidak berubah.

Aturan poligami dalam Undang-undang Hukum Keluarga Tunisia diatur dalam pasal 18, UU No. 7 Tahun 1981, menyatakan bahwa :

a. Poligami dilarang, siapa saja yang telah menikah sebelum perkawinan pertamanya benar-benar berakhir, lalu menikah lagi, akan dikenakan hukuman penjara selama satu tahun atau membayar denda sebesar 240.000 malims atau dengan keduanya.

b. Siapa yang telah menikah, melanggar aturan yang terdapat pada UU No. 3 tahun 1957 tertanggal 4 Muharram 1377 (1 Agustus 1957) berkenaan dengan peraturan tentang status sipil dan bagi seseorang yang melakukan kontrak nikah kedua sementara ia masih dalam status nikah dengan isteri pertama, maka akan dikenakan hukuman yang sama.

c. Siapa yang dengan sengaja menikahkan seseorang yang dikenakan hukuman, menurut ketentuan yang resmi, ia bisa juga dikenakan hukuman yang sama.

\footnotetext{
${ }^{9}$ Norman Anderson, Law Reform in the Muslim World (London: The Athlone Press, 1976), h. 63

${ }^{10}$ Khoiruddin Nasution, Perdebatan Singkat Status Poligami: Ditinjau dari Persepekti Syariah Islam, dalam Musawa, Vol. I No. I, Maret 2002, h. 78.
} 
d. Pasal 53 tentang hukum pidana tidak diterapkan dalam pasal ini. ${ }^{11}$

Reformasi hukum yang dilakukan Tunisia berupaya melakukan kesetaraan hak antara laki-laki dan perempuan. Dalam Undang-undang Keluarga Tunisia, status wanita sama derajatnya dengan laki-laki. Meskipun secara eksplisit The Code of Personal Status tidak merujuk pada teks suci Islam, tetapi secara implisit menunjukkan ajaran-ajaran Islam berperan besar terhadap pembentukannya.

\section{Alasan larangan poligami di Tunisia}

Berdasarkan kondisi sosio-politik yang melatari lahirnya Undangundang poligami Tunisia, maka dapat diketahui alasan mendasar mengapa poligami dilarang. Hal ini disebabkan oleh faktor kondisi sosial dalam praktek masyarakat. Praktik poligami di Tunisia pada kenyataannya menyengsarakan pihak isteri dan anak. Pelaku poligami tidak dapat berlaku adil terhadap isteri-isterinya. oleh karena itu, praktik poligami tidak sejalan dengan syarat yang diharuskan al-Quran.

Sementara itu, alasan yang digunakan oleh pemerintah Tunisia dalam pelarangan poligami tersebut ada dua. Pertama, bahwa pada masa modern sekarang masyarakat telah menjadi masyarakat yang selalu berpikir mengedepankan keadilan, karena itu, institusi perbudakan dan poligami dilarang, sebab kedua institusi ini hanya boleh pada masa perkembangan. Kedua, surat an-Nisa : 3 , yang menetapkan bahwa syarat mutlak seorang suami boleh poligami adalah jika dapat berlaku adil terhadap isteri-isterinya sedangkan fakta sejarah membuktikan hanya Nabi yang dapat berlaku adil terhadap isteri-isterinya. ${ }^{12}$

Jika kita melihat alasan pemerintah Tunisia dalam penetapan larangan poligami di atas, sudah sesuai dengan ajaran-ajaran dalam Islam. Dasar pertimbangan yang diambil oleh pemerintah Tunisia dalam membuat UU bukan hanya dasar konsep murni, tetapi sudah dipadukan dengan fakta yang terjadi di lapangan. Akhirnya dirumuskanlah sebuah

\footnotetext{
${ }^{11}$ Mahmood, Statutes of Personal Law, h. 173.
}

${ }^{12}$ Norman Andrerson, Law Reform, h. 110 
aturan formal yang bertujuan melarang praktik poligami. Maka pada Tahun 1957, ditetapkanlah Code of Personal Status No. 66 Tahun 1956 yang melarang poligami secara mutlak.

Tampak jelas bahwa perumusan dan penetapan UU Keluarga khususnya tentang larangan poligami tidak lepas dari sosok presiden pertama Tunisia Habib Bourguiba. Melalui kekuasaan politiknya, ia berusaha melakukan pembaharuan yang begitu signifikan terhadap pembentukan Code of Personal Status Tunisia yang mengarah pada persamaan hak dan kewajiban antara laki-laki dan perempuan di depan Hukum.

Gagasan larangan poligami yang didengungkan oleh Habib Bourguiba tersebut tentunya tidak lepas dari ketertarikan dan keberpihakan dalam meneruskan ide-ide tokoh pembaharu Muhammad Abduh sebagai tokoh pembaharu abad 20.13 Salah satu pendapatnya yang populer adalah bahwa poligami sebagai suatu tindakan yang tidak boleh atau haram, jika tujuannya hanya sekedar bersenang-senang atau pemuas nafsu. Poligami hanya mungkin bisa dilakukan seorang suami dalam hal-hal tertentu, misalnya ketidakmampuan seorang isteri untuk mengandung atau melahirkan. Meskipun poligami dibolehkan, tetapi dituntut dengan syarat harus bisa berlaku adil,, baik dari segi adil materi maupun adil dalam hal cinta dan kasih sayang. Dirasa syarat yang harus dilakukan sangat berat maka pada intinya tujuan dari perkawinan adalah monogami. Pemikir Muhammad Abduh inilah banyak mengilhami Habib Bourguiba dalam melakukan reformasi hukum Islam, terutama dalam hal larangan poligami.

Berdasarkan pasal 18 Code of personal Status No. 66 Tahun 1956 yang melarang poligami secara mutlak, maka secara formal terdapat aturan yang dinilai dapat menekan adanya kesewenangan suami terhadap

${ }^{13}$ Menurut Esposito, Habib Bourguiba berusaha ingin memproyeksikan dirinya sebagai pembaharu Muslim dalam tradisi Muhammad Abduh. Artinya, melalui ajaran-ajaran Abduh, Habib Bourguiba melakukan reformasi terhadap hukum Islam melalui jalur kekuasaan. John L. Esposito, Ensiklopedi-Oxford Dunia Islam Modern, terj. Eva Y.N, dkk (Bandung: Mizan, 2001), IV: 58; Khoiruddin Nasution, Riba \& Poligami : Sebuah Studi atas Pemikiran Muhammad Abduh, cet. I (Yogyakarta; Pustaka Pelajar bekerjasama dengan academia,1996), h. 106. 
isteri. Hal ini dikarenakan dalam pasal tersebut terdapat sanksi tegas bagi pelanggarnya, yaitu penjara satu tahun atau denda 240.000 malims dan bisa juga dikenakan kedua-duanya sekaligus.

Banyak kalangan berpendapat bahwa secara umum materi UU Hukum Keluarga Tunisia merupakan aturan hukum yang menempatkan wanita sejajar dengan kaum laki-laki. Aturan-aturan tersebut dinilai emansipatoris dan tidak bias jender serta dianggap telah melangkah lebih jauh dari konsep figh klasik terutama sekali dalam masalah poligami. Hal inilah yang menjadi ciri negara Tunisia jika dibandingkan dengan negaranegara muslim lainnya khususnya tentang larangan poligami. Negara muslim lainnya pada satu sisi melarang poligami namun pelarangannya hanya terbatas pada mempersulit izin poligami.

Berdasarkan upaya progresif pemerintah Tunisia dalam membela kaum wanita di atas, David Pear menilai bahwa negara Tunisia ingin modern tetapi tetap melandaskan penetapan larangan poligami pada alQuran, intinya tetap berada pada koridor agama. Dengan demikian, negara Tunisia adalah negara ketiga yang melarang poligami secara mutlak setelah negara Turki dan Lebanon.

Secara filosofi, tujuan diberlakukannya larangan poligami dalam perundang-undangan Tunisia memiliki tujuan yang baik, yaitu demi terciptanya keluarga sakinah, mawaddah dan rahmah dalam masyarakat Tunisia. Hal ini sebagai problem solving terhadap banyaknya praktik poligami di masyarakat Tunisia yang menyengsarakan pihak isteri dan anak-anak, sehingga tujuan dari perkawinan tidak terwujud. Bahkan secara yurudis, memberlakukan sanksi terhadap suami yang melakukan poligami.

Namun jika kita melihat lebih dalam lagi terhadap penerapan perundang-undangan ini, masih banyak masyarakat yang tidak menerapkan peraturan tersebut, dirasa belum maksimal. Salah satu penyebab tidak efektifnya pemberlakuan aturan tersebut adalah reformasi yang dilakukan oleh pemerintahan Tunisia lebih banyak menerapkan teori 
top down, bukan dari kesadaran seluruh masyarakat yang menginginkan adanya perubahan dalam pemberlakuan hukum Islam menjadi hukum positif.

Dengan demikian, pembuatan peraturan tidak hanya berangkat dari inisiatif pemerintah saja, tapi juga harus mendengarkan pendapat dari masyarakat pada umumnya. Tujuannya adalah agar dalam pelaksanaannya murni berdasarkan kesadaran masyarakat, bukan karena keterpaksaan.

\section{Penutup}

Pada penjelasan di atas, dapat kita tarik kesimpulan bahwa negara Tunisia dalam penerapan perundang-undangan tentang larangan poligami tidak lepas dari unsur sosial budaya. Faktor di lapangan, dengan banyaknya para suami yang menyengsarakan pihak isteri dan anak. Inilah salah satu penyebab yang menjadikan berlakunya perundang-undangan tentang larangan poligami. Karena ketidakadilan yang dilakukan suami terhadap para isterinya. Tetapi pada kenyataannya peraturan larangan poligami tersebut berjalan masih belum maksimal. Ini disebabkan karena tidak adanya kesamaan kehendak antara pemerintah dan masyarakat.

Kedepannya semoga perundang-undangan hukum keluarga bisa berjalan dengan maksimal dan benar-benar menciptakan keluarga yang penuh dengan kasih sayang tanpa adanya poligami.

\section{Daftar Pustaka}

Mahmood,Tahir. Statutes of Personal Law in Islamic Coutries: History, Texts and analysis, Edisi revisi II. 1995. New Delhi: ALR.

Muzdhar, M. Atho' dan Khairuddin Nasution, Hukum Keluarga Di Dunia Islam Modern, 2003. Jakarta: Ciputat Press. 
Muzhar, M. Atho. Membaca Gelombang litihad: antara Tradisi dan Liberasi, cet. I. 1998. Yogyakarta: Titian Ilahi Press.

Nasution, Khoiruddin. Riba \& Poligami : Sebuah Studi atas Pemikiran Muhammad Abduh, cet. I. 1996. Yogyakarta; Pustaka Pelajar bekerjasama dengan academia.

P. Entelis, John. "Tunisia" dalam John L. Esposito dkk. (ed) The Oxport Encyclopedia Of The Modern Word, 1995. New York: Oxford University Press.

El-Alami, Dawoud dan Hinchliffe, Islamic Marriage and Divorce Laws of the Arab World. 1996. London: The hague, Boston: Kluwer Law International.

Carolin Fluehr-Lobban, Islamic Siciety in Practice, 1994.Florida: University Press of Florida.

Anderson, Norman. Law Reform in the Muslim World. 1976. London: The Athlone Press.

Nasution, Khoiruddin. Perdebatan Singkat Status Poligami: Ditinjau dari Persepekti Syariah Islam, dalam Musawa, 2002. Vol. I No. I, Maret. 